\title{
PRENATAL, EARLY LIFE, AND CHILDHOOD EXPOSURE TO GENOTOXICANTS IN THE LIVING ENVIRONMENT
}

\author{
Jelena KATIĆ ${ }^{1}$, Aleksandra FUČIĆ ${ }^{1}$, and Marija GAMULIN² \\ Institute for Medical Research and Occupational Health ${ }^{1}$, Clinical Hospital Centre Zagreb², Zagreb, Croatia
}

Received in August 2010

Accepted in November 2010

\begin{abstract}
Health disorders and diseases related to environmental exposure in children such as cancer and immunologic disturbances (asthma, allergies) are on the rise. However, complex transplacental and prepubertal genotoxicology is given very limited consideration, even though intrauterine development and early childhood may be critical for elucidating the cancer aetiology. The foetus is transplacentally exposed to contaminants in food and environment such as various chemicals, drugs, radiochemically contaminated water and air. Target organs of xenobiotic action may differ between the mother and the foetus due to specific stage of developmental physiology and enzyme distribution. This in turn may lead to different levels of clastogenic and aneugenic metabolites of the same xenobiotic in the mother and the foetus. Adult's protective behaviour is not sufficient to isolate children from radioisotopes, pesticides, toxic metals and metalloids, environmental tobacco smoke, endocrine disrupting chemicals, and various food contaminants, which are just a part of the stressors present in a polluted environment. In order to improve legislation related to foetus and child exposure to genotoxic and possibly carcinogenic agents, oncologists, paediatricians, environmental health specialists, and genotoxicologists should work together much more closely to make a more effective use of accumulated scientific data, with the final aim to lower cancer incidence and mortality.
\end{abstract}

KEY WORDS: child genotoxicology, environmental exposure, genome damage, transplacental genotoxicology, xenobiotics

Health disorders and diseases related to environmental exposure in children such as cancer and immunologic disturbances (asthma, allergy) are on a constant rise (1-3). The increased risk of cancer could be the result of in utero and early life exposure (4). Carcinogenesis could start during the specifically vulnerable period of foetal development as a consequence of maternal exposure to food and environmental mixture of pollutants $(5,6)$. The complex interaction between the environment and a living organism is modified by processes of growth, development, adaptation, and aging. Challenges to developmental homeostasis may burden adulthood with different health risks and deviations in processes of ageing. Radiation and chemical carcinogens can damage the genome through direct interaction with DNA, formation of free radicals, disturbances of lipid peroxidation, and hypomethylation (7-9). As it seems that almost all cancers are oestrogen-related, evaluation of carcinogens demands a new approach (10-12). Oestrogen-like activity has been described for known or suspected genotoxic agents such as metals, heterocyclic amines, some pesticides, and dioxins (13-16). Cotinine (a nicotine metabolite) and some fungicides are, in contrary, aromatase inhibitors $(17,18)$. Oestrogen also has a significant role in 
organogenesis and in maturation during the pubertal period (19). In addition, hormone levels can cause specific radiochemical sensitivity (20).

Genome damage in the foetus is a result of a complex interaction between maternal and foetal metabolism, development stage of the foetus, pregnancy-related bioaccumulation of metabolites and detoxification capacity of the foetus and the mother (including endometrium) (21). Interaction between the xenobiotics and their metabolites even at low doses may be synergistic and long-term. Furthermore, production of clastogenic or aneugenic metabolites of the same xenobiotic can differ between the first and the third trimester of pregnancy. Drugs like paracetamol, 5-nitrofurantoin, or fluconazole, which are frequently prescribed in paediatric practice, are potential transplacental and postnatal genotoxicants as is found in the latest investigations in young animals $(22,23)$.

Human population, is exposed to hazardous biological and chemical agents through air, water, or food (Figure 1). The foetus is exposed to (radio)chemical genotoxicants from the occupational and living environment of the mother and father and for children it is water, air at home and school (indoor), urban or rural open air microenvironment and food. The effects of exposure to lead, polychlorinated biphenyls (PCBs), radioisotopes, environmental tobacco smoke, mercury, endocrine disrupters, pesticides, and food contaminants are often combined with drugs (including recreational ones) and stress at school, in the family (such as divorce) or society (such as war), infection and malnutrition.

All too often environmental risks are recognised when it is too late, that is, through epidemiological studies, when health consequences are already there. Genotoxicological methods in properly modelled studies, can identify genome damage and health risk before the first clinical symptoms. The most informative result is produced by measuring the final biological effect, which summarises all synergistic and antagonistic mechanisms of xenobiotics. Molecular epidemiology uses biomarkers that can measure the concentration of xenobiotics and their metabolites (biomarkers of exposure), individual's susceptibility (biomarkers of susceptibility), and early biological effects through molecular and cellular changes (biomarkers of effect). These biomarkers of effect include chromosome abberation (CA), micronuclei $(\mathrm{MN})$, and sister chromatid exchange (SCE), which are used in biomonitoring. $\mathrm{CA}$ and $\mathrm{MN}$ correlate with increased cancer risk $(24,25)$. Another valuable tool, the comet assay, has been used to measure genotoxic effects and individual susceptibility in humans. Despite its advantages such as great sensitivity and small sample size required, the comet assay has not yet been standardised with a protocol and a quality control programme $(26,27)$.

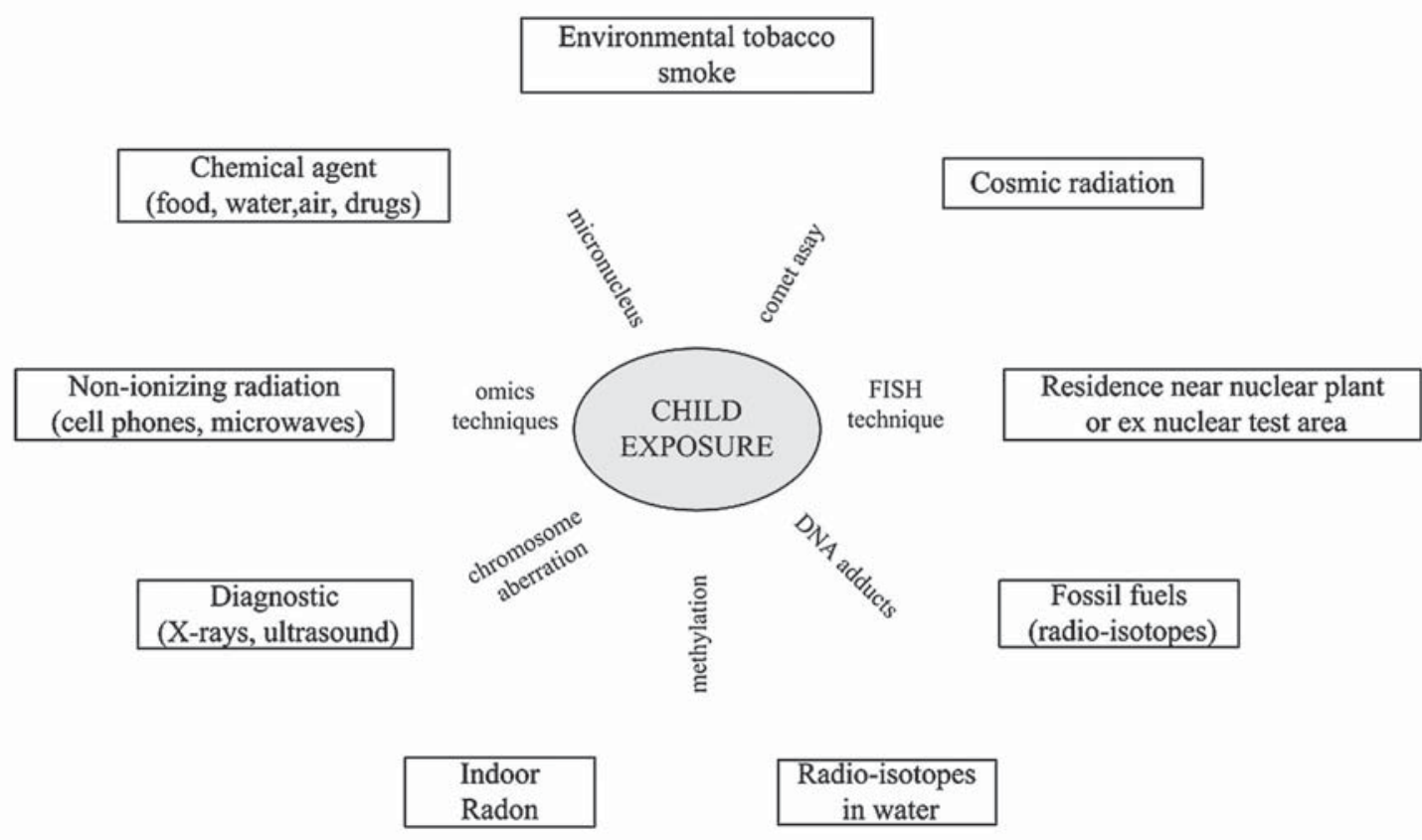

Figure 1 Children's exposure to physical and chemical agents and applied biomarkers of susceptibility, exposure, and effect 
Infants and children are generally omitted from large-scale biomonitoring studies because of ethical reasons. Literature search showed that applied genotoxicological methods are sensitive to genome damage in children caused by xenobiotics like those from environmental tobacco smoke and air pollution $(28,29)$. In a meta-analysis by Neri et al. (28), CA and $\mathrm{MN}$ were increased in children exposed to industrial pollutants, chemical waste, polluted water, indoor radon, and environmental tobacco smoke. Although used in only a few studies, SCE also deviated from control values in children who lived downwind of a chemical disposal site (30). Several studies of child exposure to chemical agents used the following biomarkers: DNA, haemoglobin and protein adducts, comet assay, and gene mutation assay (31-35). They suggest specific susceptibility of the foetus and child and call for further search for the most sensitive methods for certain types of environmental (radio)chemicals $(30,36)$.

This paper gives an overview of child exposure to genotoxicants in food, drugs, water, air, including ionising, and non-ionizing radiation.

\section{FOOD}

Genotoxic agents are detectable in food at levels which vary depending on the type of food and preparation method. For instance, baking and broiling causes formation of acrylamide, heterocyclic amines, and benzo(a)pyrene at different levels (37-39). However, contrary to professional and environmental exposure where one can have only small influence, nutrition although defined by socioeconomic and demographic status, can be improved. Changes in dietary habits, size of meal, and cooking method can also reduce intake of contaminants. Recommendations for optimal and balanced diet are of particular importance for pregnant women in order to reduce foetal exposure. Deficiency in micronutrients (minerals, vitamins) in maternal nutrition could cause adverse health effects on foetal development $(40,41)$. So far there is not much scientific evidence confirming newborn genome damage due to maternal exposure to genotoxic chemicals present in food during pregnancy. Ross et al. report increased risk of infant leukaemia if the mother is exposed to drugs or natural substances in food that are inhibiting DNA topoisomerase II (42). One of the most investigated dietary transplacental toxicants in humans is ethanol $(\mathrm{EtOH})$. Metabolised with higher efficiency in mothers, EtOH may cause severe biological effects in the foetus due to low foetal clearance capacity (43). Chronic exposure to aflatoxin, a mycotoxin present in food, may have carcinogenic effects (44). Lipoxygenase activity caused by aflatoxin B-1 is significantly higher in prenatal than in adult liver tissue, while detoxification by epoxide hydrolase is half as effective as in adults (45).

Prenatal exposure to PCBs could adversely affect child's neurological and cognitive development (46). Karttunnen et al. (47) have shown that maternal exposure to benzo(a)pyrene can lead to placental biotransformation which produces reactive metabolites able to form stable BaP-DNA adducts in foetus. Maternal high fish consumption during pregnancy could lead to prenatal mercury and methylmercury exposure leading to foetal death or neurodevelopmental delays (48). However, there are no data on heavy-metal-related genome damage and health risk in newborns or on any late genotoxic effects during childhood.

\section{DRUGS}

Developmental toxicants became an issue in the 1960s when the use of thalidomide was shown to have deleterious effects on the foetus development (49). Since then, a number of medications have been prescribed during pregnancy but less than $10 \%$ of drugs have been investigated for teratogenic effects (50). Studies have shown that the placental barrier is permeable to drugs and their metabolites (51), but there are few of them investigating and evidencing genome damage in newborns. We have recently reported new in vivo findings of MN induction in newborns of mothers taking antiepileptic drugs during pregnancy (52). Witt et al. (53) reported a tenfold increase in micronucleated reticulocyte frequency in infants exposed to antiretroviral therapy in utero.

\section{WATER}

The usual genotoxicants in water are nitrate, arsenic, nickel, cadmium, and asbestos (54) and children exposed to them have shown genome damage $(55,56)$. Unlike tap water, bottled water 
originating from ground water can contain ${ }^{226} \mathrm{Ra}$, ${ }^{228} \mathrm{Ra},{ }^{210} \mathrm{~Pb}$, and ${ }^{210} \mathrm{Po}^{17}$ and display various levels of radioactivity (57). Its consumption has increased in order to avoid chemical contaminants in tap water, but also due to changes in eating habits and lifestyle. Several studies of bottled water samples in Europe have found beta radioactivity going up to $4.6 \mathrm{~Bq} \mathrm{~L}^{-1}$ and alfa radioactivity up to $1.75 \mathrm{~Bq} \mathrm{~L}^{-1}$, which is well above the reference limits $\left(1.0 \mathrm{~Bq} \mathrm{~L}^{-1}\right.$ and $0.1 \mathrm{~Bq} \mathrm{~L}^{-1}$, respectively) (59-60). World Health Organization (WHO) (61) recommends that the annual effective dose from water consumption does not exceed $5 \%$ of the average effective dose from natural sources $(2.4 \mathrm{mSv})$, that is, $0.1 \mathrm{mSv}$. As radon follows the metabolic pathway of calcium, its incorporation into a child' skeleton poses a significant health risk (62). Due to age-dependent development of the gastrointestinal system in children, the highest absorption of radon is in newborns and children between 13 and 17 years of age $(63,64)$. In addition, newborns and children seem to drink more water than adults (65). Undernourished infants may receive doses of up to $0.28 \mathrm{mSv}_{\text {year }}{ }^{-1}$ if their diet is exclusively prepared with mineral water with elevated radon concentrations. According to Bronzović et al. (66) ${ }^{226}$ Ra body activity is significantly higher in people exposed to high doses during childhood than those exposed at adult age. Accumulation of radon in bones during puberty may be related to specific hormonal activity of testosterone and oestrogen (67). The mechanism of ${ }^{90} \mathrm{Sr}$ bioaccumulation in the bone is similar to ${ }^{226} \mathrm{Ra}$, but according to Tolstykh et al. (68) its bone affinity is even greater, as shown in a population overexposed to ${ }^{90} \mathrm{Sr}$ near the Mayak plutonium production complex in Russia. These authors find that the most critical period for girls is just before menarche and for boys 2 to 3 years before the formation of the secondary sex features. Consequently, adults who were exposed to ${ }^{90} \mathrm{Sr}$ during the childhood have a significantly higher frequency of traslocations than young adults exposed at the age of 20 years or older (69).

In summary, water involves exposure to a complex mixture of radiochemicals. To understand their mechanisms of action one needs to be aware of several pathways including knowledge on specific early age or later hormonal level related bioaccumulation.

\section{AIR}

Children spend most of their time at home or at (pre)school, where they may be exposed to formaldehyde. This can lead to higher CA frequency $(70,71)$. Exposure to secondary tobacco smoke leads to deviations in all genotoxic biomarkers from control values for all age groups, from newborns to adolescents $(28,72)$. Hansen et al. (73) have shown that carcinogens from tobacco smoke pass through the placenta to foetal tissues and metabolise to DNAdamaging agents. They have also found that newborns of mothers who smoked and drank alcohol during pregnancy had higher translocation frequencies. Cadmium, lead, and arsenic, from tobacco smoke have 10 times higher absorption than from food or water (74). In a study by Godschalk et al. (75), foetal exposure to heavy metals such as cadmium correlated positively with the number of HPRT-variants per adduct in cord blood. The authors suggest that by inhibiting DNA repair, cadmium may enhance the genotoxic effect of other carcinogens.

Radon gas is the second leading cause of lung cancer after smoking. Apart from background radon radiation, indoor exposure is usually related to natural radioactivity from fly ash, alum shale, and phosphogypsum used in building materials (76). Stoulos et al, found increased MN and CA frequency in children exposed to high levels of indoor radon (77).

Exposure to outdoor airborne pollutants, including chemicals from suburban smelters or residential heating systems can cause genome damage in children (78-80). Pedersen et al. (81) found that maternal exposure to traffic-related air pollution in urban environment resulted in increased bulky DNA adducts and $\mathrm{MN}$ frequency in cord blood (81). A life close to mining sites may be the source of severe genome damage in children caused by arsenic or lead (82) but it may also be contaminated by radioisotopes especially if mines are followed by the nucleo-chemical industry (83).

\section{IONISING RADIATION}

Most of the data available on children's genome damage caused by ionising radiation are related to accidental overexposure in Chernobyl (Ukraine), the Techa River (Russia), and Goiânia (Brasil) or are related to medical therapy $(28,29)$. Although pregnant women are usually isolated from jobs which could jeopardise normal development of the foetus, the first trimester of pregnancy can go unnoticed, and the foetus may be exposed to increased risk. In hospitals where 
women are occupationally exposed to radioisotopes (iodine, chromium, thallium, technetium, thorium) the miscarriage incidence is significantly higher than in women occupationally exposed to X-rays (36). It seems that health effects of radioisotopes applied in diagnostics are not limited to their own radioactivity but may also be owed to contamination with lead, tin, or nickel due to the technology of production, which act as heavy metals or xenoestrogens (36).

Epidemiological studies of parental exposure to ionising radiation and cancer risk in children have been limited to post-Chernobyl accident biomonitoring of the so called liquidators, who were removing radioactive material and of the Chernobyl plant workers $(84,85)$. The health effects of nuclear power plants on nearby residents have not duly been investigated; this is particularly true for genome damage in children. Epidemiological studies showing clusters of leukaemia in these areas still need to be confirmed (86-89). Available studies are focused on childhood leukaemia cases in the population living in an area of about $5 \mathrm{~km}$ around nuclear plants. These studies suggest that beside the health risk of children whose father work at nuclear plants (90), significant increase in leukaemia cases is also present in the general population $(91,92)$. Another source of ionising radiation are diagnostic and treatment procedures in medicine (93). Kleinerman (94) found that child exposure to radiation sources used for diagnostic imaging increased the risk of cancer and was greatest for those exposed early in life (94). Doodly et al. (95) reported increased risk of breast cancer among women with scoliosis after multiple diagnostic X-ray examinations during childhood and adolescence (95).

\section{NON-IONISING RADIATION}

Human exposure to radiofrequency (RF) nonionising radiation has increased over the last decade as a result of increased use of mobile phones, especially in children and adolescents (96). Epidemiological studies in animals and humans have revealed neurological and behavioural effects of RF radiation exposure $(97,98)$. However, cancer risk assessments have remained inconclusive, and there is only one study with strong scientific evidence of association between $\mathrm{RF}$ radiation from cell phones and wireless devices and the development of acoustic neuroma and glioma, especially in people who started using mobile phones before the age of 20 years (99). Another multi-national case-control study (the Interphone study, 100), find no association between RF exposure from mobile phones and cancer risk. According to Shüz (101), newborns and children are more susceptible than adults since their nervous system is still developing. In addition, they will have much higher cumulative exposure than today's adults and the potential long-term health effects are still unknown. Therefore, current legislation should be based on the precautionary principle.

\section{CONCLUSIONS AND RECOMMENDATIONS}

Developmental characteristics of children as a response to their living environment are specific bioaccumulation, absorption, distribution, foetal and transitional perinatal metabolic and detoxification enzymes and kidney clearance (102). Adult values for glomerular filtration rate, maximum tubular excretory capacity, and maximum renal concentrating capacity are achieved by the age of 2 years. Foetuses and newborns up to 3 months of age have significantly different cytochrome P450 levels than adults, which results in different circulatory half-life for a number of substances (103). Therefore, paediatric pharmacology could help to better understand the mechanisms of action of environmental genotoxicants and to better assess the related risks (104). Similarly, knowledge of metabolic kinetic and chemical structure of environmental xenobiotics, can be used in research of new drugs.

Specific research is needed to investigate environmental impact mediated by complex hormonal changes during puberty. The interaction between PCBs, dibenzodioxins, phyto-oestrogens, cadmium or DDT and endogenous hormones $(105,106)$ has to be further investigated because of their potential to sensitise mechanisms leading to increased genome damage by other genotoxic agents from the environment (107).

In transplacental studies, knowledge of metabolism during intrauterine development should be incorporated in interpretation of results, as the same xenobiotics may cause different levels of genome damage in different foetal tissues through time.

Future research demands: pharmacokinetic studies across different developmental stages, molecular characterisation of target-binding sites, and better understanding of the synthesis and activation of 
nuclear proteins (transcription factors), nucleotide pool disturbances, and impact of lipid peroxidase products (4-hydroxynonenal and malondialdehyde).

Over the last few decades, genotoxicology and developmental genotoxicology have been limited to frozen time segment insights into the mechanisms that lead to genome damage. Introduction of systems biology, a new field which develops a system-level understanding of biology (108) enables analysis of dynamics of the systems, optimal frame for interpretation of collected data on the interaction between environment and known developmental mechanisms. Recent advances have demonstrated that molecular regulatory networks can be modelled in mathematical terms. Such approach will prevent hundreds of genotoxicological results and especially results from gene and protein arrays to serve simply as a catalogue of change (109).

Induction of bystander effect, adaptive response and genome instability after xenbiotic exposure can have negative effects on the complexity of foetal development causing imbalance in gene expression (110). This is why future research should investigate adaptive response and its relation to interindividual variability in response to xenobiotics, genome instability, and sensitivity to radiation or chemicals.

Future research should also focus on mechanisms by which hormonal disruptors increase oestrogen, which in turn (111) may interact with radiation and increase cancer risk (112).

Close collaboration of occupational and environmental health specialists with paediatricians, genotoxcologists and oncologists can significantly improve the quality and applicability of available knowledge. Dataset gridding of these four fields could incorporate all aspects of life, from foetal development to parental working environment, and make it possible to evaluate cancer risk for each individual.

\section{Acknowledgement}

This work was supported by the EU project HENVINET 6th Framework Programme, Coordination Action (Contract no.037019), (http://www.henvinet.org) and by the Ministry of Science, Education and Sports of the Republic Croatia, as a part of the Grant No. 022-0222148-2137.

\section{REFERENCES}

1. Steliarova-Foucher E, Stiller C, Kaatsch P, Berrino F, Coebergh JW, Lacour B, Parkin M. Geographical patterns and time trends of cancer incidence and survival among children and adolescents in Europe since the 1970s (the ACCIS project): an epidemiological study. Lancet 2004;364:2097-105.

2. Grandjean P, Bellinger D, Bergman A, Cordier S, DaveySmith G, Eskenazi B, Gee D, Gray K, Hanson M. The Faroes statement: human health effects of developmental exposure to chemicals in our environment. Basic Clin Pharmacol Toxicol 2008;102:73-5.

3. Carlsen KH. Astma - en tilstand for vår tid, en tilstand i forandring? [Asthma - a condition of our time, a condition in change? in Norwegian]. Tidsskr Nor Laegeforen 2001;121:836-40.

4. Mongraw-Chaffin ML, Cohn BA, Anglemyer AT, Cohen RD, Christianson RE. Maternal smoking, alcohol, and coffee use during pregnancy and son's risk of testicular cancer. Alcohol 2009;43:241-5.

5. Li S, Hursting SD, Davis BJ, McLachlan JA, Barrett JC. Environmental exposure, DNA methylation, and gene regulation: lessons from diethylstilbesterol-induced cancers. Ann NY Acad Sci 2003;983:161-9.

6. Gluckman PD, Hanson MA, Cooper C, Thornburg KL. Effect of in utero and early-life conditions on adult health and disease. N Engl J Med 2008;359:61-73.

7. Toyokuni S. Molecular mechanisms of oxidative stressinduced carcinogenesis: from epidemiology to oxygenomics. IUBMB Life 2008;60:441-7.

8. Mikhailov VF, Mazurik VK, Burlakova EB. [Signal function of the reactive oxygen species in regulatory networks of the cell reaction to damaging effects: contribution of radiosensitivity and genome instability, in Russian]. Radiat Biol Radioecol 2003;43:5-18

9. Ilnytskyy Y, Koturbash I, Kovalchuk O. Radiation-induced bystander effects in vivo are epigenetically regulated in a tissue-specific manner. Environ Mol Mutagen 2009;50:10513.

10. Schwartz AG, Prysak GM, Murphy V, Lonardo F, Pass H, Schwartz J, Brooks S. Nuclear estrogen receptor beta in lung cancer: expression and survival differences by sex. Clin Cancer Res 2005;11:7280-7.

11. Tanaka Y, Sasaki M, Kaneuchi M, Fujimoto S, Dahiya R. Estrogen receptor alpha polymorphisms and renal cell carcinoma - a possible risk. Mol Cell Endocrinol 2003;202:109-16.

12. Konduri S, Schwarz RE. Estrogen receptor beta/alpha ratio predicts response of pancreatic cancer cells to estrogens and phytoestrogens. J Surg Res 2007;140:55-66.

13. Wang SL, Chang YC, Chao HR, Li CM, Li LA, Lin LY, Papke O. Body burdens of polychlorinated dibenzo-pdioxins, dibenzofurans, and biphenyls and their relations to estrogen metabolism in pregnant women. Environ Health Perspect 2006;114:740-5.

14. Bennion BJ, Cosman M, Lightstone FC, Knize MG, Montgomery JL, Bennett LM, Felton JS, Kulp KS. PhIP carcinogenicity in breast cancer: computational and experimental evidence for competitive interactions with human estrogen receptor. Chem Res Toxicol 2005;18:152836.

15. Stefanidou M, Maravelias C, Spiliopoulou C. Human exposure to endocrine disruptors and breast milk. Endocr Metab Immune Disord Drug Targets 2009;9:269-76.

16. Turner KJ, Sharpe RM. Environmental oestrogens - present understanding. Rev Reprod 1997;2:69-73. 
17. Barbieri RL, Gochberg J, Ryan KJ. Nicotine, cotinine, and anabasine inhibit aromatase in human trophoblast in vitro. J Clin Invest 1986;77:1727-33.

18. Birnbaum LS, Fenton SE. Cancer and developmental exposure to endocrine disruptors. Environ Health Perspect 2003;111:389-94.

19. Rosenthal MD, Albrecht ED, Pepe GJ. Estrogen modulates developmentally regulated gene expression in the fetal baboon liver. Endocrine 2004;23:219-28.

20. Krol M, Lankoff A, Buraczewska I, Derezinska E, Wojcik A. Radiation-induced micronucleus frequencies in female peripheral blood lymphocytes collected during the first and second half of the menstrual cycle. Radiat Prot Dosim 2007; $123: 483-9$

21. Alexandrov VA. Role of the maternal organism in transplacental carcinogenesis. IARC Sci Publ 1983;51:6579.

22. Fucic A, Markovic D, Ferencic Z, Mildner B, Jazbec AM, Spoljar JB. Comparison of genomic damage caused by 5 -nitrofurantoin in young and adult mice using the in vivo micronucleus assay. Environ Mol Mutagen 2005;46:59-63.

23. Fucic A, Markovic D, Herceg Z, Gamulin M, Katic J, Stojkovic R, Ferencic Z, Mildner B, Jazbec AM, Dobranic T. Developmental and transplacental genotoxicology: fluconazole. Mutat Res 2008:657:43-7.

24. Boffetta $\mathrm{P}$, van der Hel O, Norppa H, Fabianova E, Fucic A, Gundy S, Lazutka J, Cebulska-Wasilewska A, Puskailerova D, Znaor A, Kelecsenyi Z, Kurtinaitis J, Rachtan J, Forni A, Vermeulen R, Bonassi S. Chromosomal aberrations and cancer risk: results of a cohort study from Central Europe. Am J Epidemiol 2007;165:36-43.

25. Bonassi S, Znaor A, Ceppi M, Lando C, Chang WP, Holland N, Kirsch-Volders M, Zeiger E, Ban S, Barale R, Bigatti MP, Bolognesi C, Cebulska-Wasilewska A, Fabianova E, Fucic A, Hagmar L, Joksic G, Martelli A, Migliore L, Mirkova E, Scarfi MR, Zijno A, Norrpa H, Fenech M. An increased micronucleus frequency in peripheral blood lymphocytes predicts the risk of cancer in humans. Carcinogenesis 2007;28:625-31.

26. Dusinska M, Collins AR. The comet assay in human biomonitoring: gene-environment interactions. Mutagenesis 2008;23:191-205.

27. Møller P, Möller L, Godschalk RW, Jones GD. Assessment and reduction of comet assay variation in relation to DNA damage: studies from the European Comet Assay Validation Group. Mutagenesis 2010;25:109-11.

28. Neri M, Ugolini D, Bonassi S, Fucic A, Holland N, Knudsen LE, Sram RJ, Ceppi M, Bocchini V, Merlo DF. Children's exposure to environmental pollutants and biomarkers of genetic damage. II. Results of a comprehensive literature search and meta-analysis. Mutat Res 2006;612:14-39.

29. Neri M, Fucic A, Knudsen LE, Lando C, Merlo F, Bonassi S Micronuclei frequency in children exposed to environmental mutagens: a review. Mutat Res 2003;544:243-54.

30. Vleminckx C, Klemans W, Schriewer L, Joris I, Lijsen N, Ottogali M, Pays A, Planard C, Rigaux G, Ros Y, Vande Rivière M, Vandenvelde J, De Plaen P, Lakhanisky TH, Maes A, Verschaeve L. Performance of cytogenetic biomarkers on children exposed to environmental pollutants. Toxicol Ind Health 1997;13:219-30.

31. Autrup H. Transplacental transfer of genotoxins and transplacental carcinogenesis. Environ Health Perspect 1993;101:33-8.
32. Tang D, Warburton D, Tannenbaum SR, Skipper P, Santella RM, Cereijido GS, Crawford FG, Perera FP. Molecular and genetic damage from environmental tobacco smoke in young children. Cancer Epidemiol Biomarkers Prev 1999;8:42731.

33. Ammenheuser MM, Berenson AB, Stiglich NJ, Whorton EB, Jr., Ward JB, Jr. Elevated frequencies of hprt mutant lymphocytes in cigarette-smoking mothers and their newborns. Mutat Res 1994;304:285-94.

34. Schettgen T, Kutting B, Hornig M, Beckmann MW, Weiss T, Drexler H, Angerer J. Trans-placental exposure of neonates to acrylamide - a pilot study. Int Arch Occup Environ Health 2004;77:213-6.

35. Sampayo-Reyes A, Hernández A, El-Yamani N, LópezCampos C, Mayet-Machado E, Rincón-Castañeda CB, Limones-Aguilar Mde L, López-Campos JE, de León MB, González-Hernández S, Hinojosa-Garza D, Marcos R. Arsenic induces DNA damage in environmentally exposed Mexican children and adults. Influence of GSTO1 and AS3MT polymorphisms. Toxicol Sci 2010;117:63-71.

36. Fucic A, Merlo DF, Ceppi M, Lucas JN. Spontaneous abortions in female populations occupationally exposed to ionizing radiation. Int Arch Occup Environ Health 2008;81:873-9.

37. Alaejos MS, Gonzalez V, Afonso AM. Exposure to heterocyclic aromatic amines from the consumption of cooked red meat and its effect on human cancer risk: a review. Food Addit Contam Part A Chem Anal Control Expo Risk Assess 2008;25:2-24.

38. Amrein TM, Andres L, Escher F, Amadò R. Occurrence of acrylamide in selected foods and mitigation options. Food Addit Contam 2007;24:13-25.

39. Kazerouni N, Sinha R, Hsu CH, Greenberg A, Rothman N. Analysis of 200 food items for benzo[a]pyrene and estimation of its intake in an epidemiologic study. Food Chem Toxicol 2001;39:423-36.

40. Kontic-Vucinic O, Sulovic N, Radunovic N. Micronutrients in women's reproductive health: I. Vitamins. Int J Fertil Womens Med 2006;51:106-15.

41. Kontic-Vucinic O, Sulovic N, Radunovic N. Micronutrients in women's reproductive health: II. Minerals and trace elements. Int J Fertil Womens Med 2006;51:116-24.

42. Ross JA, Potter JD, Reaman GH, Pendergrass TW, Robison LL. Maternal exposure to potential inhibitors of DNA topoisomerase II and infant leukemia (United States): a report from the Children's Cancer Group. Cancer Causes Control 1996; 7:581-90.

43. Nava-Ocampo AA, Velázquez-Armenta Y, Brien JF, Koren G. Elimination kinetics of ethanol in pregnant women. Reprod Toxicol 2004;18:613-7.

44. Wild CP, Montesano R. A model of interaction: aflatoxins and hepatitis viruses in liver cancer aetiology and prevention. Cancer Lett 2009;286:22-8

45. Doi AM, Patterson PE, Gallagher EP. Variability in aflatoxin $\mathrm{B}(1)$-macromolecular binding and relationship to biotransformation enzyme expression in human prenatal and adult liver. Toxicol Appl Pharmacol 2002;181:48-59.

46. Boersma ER, Lanting CI. Environmental exposure to polychlorinated biphenyls (PCBs) and dioxins. Consequences for longterm neurological and cognitive development of the child lactation. Adv Exp Med Biol 2000;478:271-87. 
47. Karttunen V, Myllynen P, Prochazka G, Pelkonen O, Segerbäck D, Vähäkangas K. Placental transfer and DNA binding of benzo(a)pyrene in human placental perfusion. Toxicol Lett 2010;197:75-81.

48. Diez S, Delgado S, Aguilera I, Astray J, Perez-Gomez B, Torrent M, Sunyer J, Bayona JM. Prenatal and early childhood exposure to mercury and methylmercury in Spain, a high-fish-consumer country. Arch Environ Contam Toxicol 2009;56:615-22.

49. Leck IM, Millar EL. Incidence of malformations since the introduction of thalidomide. Br Med J 1962;2:16-20.

50. van Gelder MMHJ, van Rooij IALM, Miller RK, Zielhuis GA, de Jong-van den Berg LTW, Roeleveld N. Teratogenic mechanisms of medical drugs. Hum Reprod Update 2010;16:378-94.

51. Włoch S, Pałasz A, Kamiński M. Active and passive transport of drugs in the human placenta. Ginekol Pol 2009;80:7727.

52. Fucic A SR, Miskov S, Zeljezic D, Markovic D, Gjergja R, Katic J, Jazbec AM, Ivicevic Bakulic T, Demarin V. Transplacental genotoxicity of antiepileptic drugs:animal model and pilot study on mother/newborn cohort. Reprod Toxicol 2010 Oct 16. [Epub ahead of print] doi:10.1016/ j.reprotox.2010.08.008

53. Witt KL, Cunningham CK, Patterson KB, Kissling GE, Dertinger SD, Livingston E, Bishop JB. Elevated frequency of micronucleated erythrocytes in infants exposed to zidovudine in utero and postpartum to prevent motherto-child transmission of HIV. Environ Mol Mutagen 2007;48:322-29.

54. Cantor KP. Carcinogens in drinking water: the epidemiologic evidence. Rev Environ Health 2010;25:9-16.

55. Dulout FN, Grillo CA, Seoane AI, Maderna CR, Nilsson R, Vahter M, Darroudi F, Natarajan AT. Chromosomal aberrations in peripheral blood lymphocytes from native Andean women and children from northwestern Argentina exposed to arsenic in drinking water. Mutat Res 1996;370:1518.

56. Tsezou A, Kitsiou-Tzeli S, Galla A, Gourgiotis D, Papageorgiou J, Mitrou S, Molybdas PA, Sinaniotis C. High nitrate content in drinking water: cytogenetic effects in exposed children. Arch Environ Health 1996;51:458-61.

57. Dávila Rangel JI, López del Rio H, Mireles García F, Quirino Torres LL, Villalba ML, Colmenero Sujo L, Montero Cabrera ME. Radioactivity in bottled waters sold in Mexico. Appl Radiat Isot 2002;56:931-6.

58. Kovács T, Bodrogi E, Dombovári P, Somlai J, Németh C, Capote A, Tarján S. ${ }^{238} \mathrm{U},{ }^{226} \mathrm{Ra},{ }^{210} \mathrm{Po}$ concentrations of bottled mineral waters in Hungary and their committed effective dose. Radiat Prot Dosimetry 2004;108:175-81.

59. Marovic G, Sencar J. Exposure to natural radioactivity from thermal waters in Croatia. Bull Environ Contam Toxicol 2001;67:35-41.

60. World Health Organization (WHO). Guidelines for drinkingwater quality. $3^{\text {rd }}$ ed. Vol. 1, Recommendations. Geneva: WHO; 2004.

61. Schlenker RA, Keane AT, Holtzman RB. The retention of ${ }^{226} \mathrm{Ra}$ in human soft tissue and bone; implications for the ICRP 20 alkaline earth model. Health Phys 1982;42:671-93.

62. Somlai J, Horvath G, Kanyar B, Kovacs T, Bodrogi E, Kavasi $\mathrm{N}$. Concentration of ${ }^{226} \mathrm{Ra}$ in Hungarian bottled mineral water. J Environ Radioact 2002;62:235-40.
63. International Commission on Radiological Protection (ICRP). Age dependent doses to members of the public from intake of radionuclides: Part 2 Ingestion dose coefficient. ICRP Publication 67. Ann ICRP 1993;23(3/4).

64. Sichr-Hellert MKF, Manz M. Fifteen years trends in water intake in German children and adolescents: results of the DONALD Study. Acta Paediatr 2001;90:732-7.

65. Rommens C, Ringeard C, Hubert P. Exposure of red bone marrow to ionizing radiation from natural and medical sources in France. J Radiat Prot 2001;21: 209-219.

66. Bronzovic M, Marovic G, Vrtar M, Bituh T. Life exposure to ${ }^{226} \mathrm{Ra}$ and possible consequences. J Environ Sci Health A Tox Hazard Subst Environ Eng 2007;42:817-23.

67. Bronzovic M, Marovic G. Age-dependent dose assessment of ${ }^{226} \mathrm{Ra}$ from bottled water intake. Health Phys 2005;88:4805 .

68. Tolstykh EI, Kozheurov VP, Vyushkova OV, Degteva MO. Analysis of strontium metabolism in humans on the basis of the Techa river data. Radiat Environ Biophys 1997;36:259.

69. Bauchinger M, Salassidis K, Braselmann H, Vozilova A, Pressl S, Stephan G, Snigiryova G, Kozheurov VP, Akleyev A. FISH-based analysis of stable translocations in a Techa River population. Int J Radiat Biol 1998;73:605-12.

70. Dobiáš L, Hanzl J, Rössner P, Janča L, Rulíšková H, Andělová S, Klementová H. [Evaluation of the clastogenic effect of formaldehyde in children in preschool and school facilities, in Czech]. Cesk Hyg 1988;33:596-604.

71. Srb V, Rossner P, Zudova Z. [Action of formaldehyde and toluene on selected cytogenetic indicators in apprentices, in Czech]. Cesk Hyg 1990;49:66-75.

72. Pluth JM, Ramsey MJ, Tucker JD. Role of maternal exposures and newborn genotypes on newborn chromosome aberration frequencies. Mutat Res 2000;465:101-11.

73. Hansen C, Asmussen I, Autrup H. Detection of carcinogenDNA adducts in human fetal tissues by the 32P-postlabeling procedure. Environ Health Perspect 1993;99:229-31.

74. Henson MC, Piasek M, Chedrese PJ, Castracane VD. Metal toxicity in mammalian reproduction. In: Eldridge JC, Stevens JT, editors. Endocrine Toxicology - Target Organ Toxicology Series. New York-London: Informa Healthcare Publishers; 2010. p. 256-79

75. Godschalk R, Hogervorst J, Albering H, MercelinaRoumans P, van Schooten FJ, de Haan J, Kleinjans J. Interaction between cadmium and aromatic DNA adducts in hprt mutagenesis during foetal development. Mutagenesis 2005;20:181-5.

76. Bilban M, Vaupoti J. Chromosome aberrations study of pupils in high radon level elementary school. Health Phys 2001;80:157-63.

77. Srám RJ, Podrazilová K, Dejmek J, Mracková G, Pilcík T. Single cell gel electrophoresis assay: sensitivity of peripheral white blood cells in human population studies. Mutagenesis 1998;13:99-103.

78. Stoulos S, Manolopoulou M, Papastefanou C. Assessment of natural radiation exposure and radon exhalation from building materials in Greece. J Environ Radioact 2003;69:225-40.

79. Perera FP, Jedrychowski W, Rauh V, Whyatt RM. Molecular epidemiologic research on the effects of environmental pollutants on the fetus. Environ Health Perspect 1999; 107:451-60. 
80. Calderon-Garciduenas L, Wen-Wang L, Zhang YJ, Rodriguez-Alcaraz A, Osnaya N, Villarreal-Calderon A, Santella RM. 8-hydroxy-2'-deoxyguanosine, a major mutagenic oxidative DNA lesion, and DNA strand breaks in nasal respiratory epithelium of children exposed to urban pollution. Environ Health Perspect 1999;107:469-74.

81. Pedersen M, Wichmann J, Autrup H, Dang DA, Decordier I, Hvidberg M, Bossi R, Jakobsen J, Loft S, Knudsen LE. Increased micronuclei and bulky DNA adducts in cord blood after maternal exposures to traffic-related air pollution. Environ Res 2009;109:1012-20.

82. Yáñez L, García-Nieto E, Rojas E, Carrizales L, Mejía J, Calderón J, Razo I, Díaz-Barriga F. DNA damage in blood cells from children exposed to arsenic and lead in a mining area. Environ Res 2003;93:231-40.

83. Druzhinin VG, Lifanov AYu, Rytenkov VYu. Cytogenetic abnormalities revealed in adolescents from Kamerovskaya oblast as indicators of adverse ecological conditions in the region. Genetica 1997;33:699-703.

84. Stepanova EI, Vanyhina EA. Clinical and cytogenetical characteristic of children born by subjects recovered of severe radiation disease I and II level as a result of Chernobyl. Tsitologiia Genetika 1993;27:10-3.

85. Weinberg ABK, Kirzhner VM, Avivi A, Fahima T, Nevo E, Shapiro S, Rennert G, Piatak O, Stepanova EI, Skvaskaja E. Very high mutation rate in offspring of Chernobyl accident liquidators. Proc R Soc Lond 2001;268:1001-05.

86. Roman E, Beral V, Carpenter L, Watson A, Barton C, Ryder $\mathrm{H}$, Aston DL. Childhood leukaemia in the West Berkshire and Basingstoke and North Hampshire District Health Authorities in relation to nuclear establishments in the vicinity. Br Med J (Clin Res Ed) 1987;294:597-602.

87. Goldsmith JR. Nuclear installations and childhood cancer in the UK: mortality and incidence for 0-9-year-old children, 1971-1980. Sci Total Environ 1992;127:13-35.

88. Gardner MJ. Father's occupational exposure to radiation and the raised level of childhood leukemia near the Sellafield nuclear plant. Environ Health Perspect 1991;94:5-7.

89. Körblein A, Hoffman W. Childhood cancer in the vicinity of German nuclear power plant. Med Glob Surviv 1999;6:18 23.

90. Parker L, Pearce MS, Dickinson HO, Aitkin M, Craft AW. Stillbirths among offspring of male radiation workers at Sellafield nuclear reprocessing plant. Lancet 1999;354:140714.

91. Schmitz-Feuerhake I, Dannheim B, Heimers A, Oberheitmann $\mathrm{B}$, Schröder H, Ziggel H. Leukemia in the proximity of a German boiling-water nuclear reactor: evidence of population exposure by chromosome studies and environmental radioactivity. Environ Health Perspect 1997;105:1499-504.

92. Mangano SJ, Cang C. Elevated childhood cancer incidence proximate to US nuclear power plants. Arch Environ Health 2003;58:74-82.

93. Ron E. Cancer risks from medical radiation. Health Phys 2003;85:47-59.

94. Kleinerman RA. Cancer risks following diagnostic and therapeutic radiation exposure in children. Pediatr Radiol 2006;36:121-5.

95. Doody M, Lonstein JE, Stovall M, Hacker DG, Luckyanov
N, Land CE. Breast cancer mortality after diagnostic radiography: findings from the U.S. Scoliosis Cohort Study. Spine 2000;25:2052-63.

96. Carpenter DO. Electromagnetic fields and cancer: the cost of doing nothing. Rev Environ Health 2010;25:75-80.

97. Repacholi MH. Health risks from the use of mobile phones. Toxicol Lett 2001;120:323-31.

98. Orendacova J, Orendac M, Racekova E, Marsala J. Neurobiological effects of microwave exposure: a review focused on morphological findings in experimental animals. Arch Ital Biol 2007;145:1-12.

99. Hardell L, Carlberg M. Mobile phones, cordless phones and the risk for brain tumours. Int J Oncol 2009;35:5-17.

100. The INTERPHONE study group. Brain tumour risk in relation to mobile telephone use: results of the INTERPHONE international case-control study. Int J Epidemiol 2010;39:67594.

101. Schüz J. Mobile phone use and exposures in children. Bioelectromagnetics 2005;S7:S45-50.

102. Scheuplein R, Charnley G, Dourson M. Differential sensitivity of children and adults to chemical toxicity. I. Biological basis. Regul Toxicol Pharmacol 2002;35:42947.

103. Hines RN, McCarver DG. The ontogeny of human drugmetabolizing enzymes: phase I oxidative enzymes. J Pharmacol Exp Ther 2002;300:355-60.

104. Ginsberg G, Hattis D, Miller R, Sonawane B. Pediatric pharmacokinetic data: implications for environmental risk assessment for children. Pediatrics 2004;113:973-83.

105. Stasenko S, Bradford EM, Piasek M, Henson MC, Varnai VM, Jurasovic J, Kusec V. Metals in human placenta: focus on the effects of cadmium on steroid hormones and leptin. J Appl Toxicol 2010;30:242-53.

106. Greim HA. The endocrine and reproductive system: adverse effects of hormonally active substances? Pediatrics 2004;113:1070-5.

107. Koppe JG, Bartonova A, Bolte G, Bistrup ML, Busby C, Butter M, Dorfman P, Fucic A, Gee D, van den Hazel P, Howard V, Kohlhuber M, Leijs M, Lundqvist C, Moshammer H, Naginiene R, Nicolopoulou-Stamati P, Ronchetti R, Salines G, Schoeters G, ten Tusscher G, Wallis MK, Zuurbier M. Exposure to multiple environmental agents and their effect. Acta Paediatr Suppl 2006;95:106-13.

108. Barabasi AL, Oltvai ZN. Network biology: Understanding the cell functional organization, Nature Reviews Genetics 2004;5:101-113

109. Andersen ME, Yang RS, French CT, Chubb LS, Dennison JE. Molecular circuits, biological switches, and nonlinear dose-response relationships. Environ Health Perspect 2002;110:971-8.

110. Streffer C. Bystander effects, adaptive response and genomic instability induced by prenatal irradiation. Mutat Res 2004;568:79-87.

111. Roy D, Liehr JG. Estrogen, DNA damage and mutations. Mutat Res 1999;424:107-15.

112. Pogribny I, Raiche J, Slovack M, Kovalchuk O. Dosedependence, sex- and tissue-specificity, and persistence of radiation-induced genomic DNA methylation changes. Biochem Biophys Res Commun 2004;320:1253-61. 


\section{Sažetak \\ IZLOŽENOST GENOTOKSIČNIM AGENSIMA IZŽIVOTNOG OKOLIŠA TIJEKOM PRENATALNOG RAZVOJA I DJETINJSTVA}

Unatoč velikim naporima da se smanji okolišna izloženost u djece se dalje bilježi trend porasta pojavnosti karcinoma i imunosnih poremećaja (astma, alergije). Premda su intrauterini razvoj i rano djetinjstvo kritično razdoblje za tumačenje etiologije nastanka karcinoma, transplacentalna i prepubertetna genotoksikologija do danas su slabo istražene. Fetus je transplacentalno izložen brojnim fizikalnim i kemijskim čimbenicima: kontaminantima iz hrane i okoliša, radiokemijski kontaminiranoj vodi, zraku te lijekovima. Ciljna tkiva za djelovanje ksenobiotika mogu biti različita u majke i fetusa zbog različitosti u razvojnoj fiziologiji i distribuciji enzima. Zbog toga u organizmu majke i fetusa mogu nastati različite razine klastogenih i aneugenih metabolita istog ksenobiotika.

Zaštitna uloga odraslih u namjeri da spriječe negativne utjecaje onečišćenog okoliša na djetetovo zdravlje često je ograničena jer su radioizotopi, olovo, PCB, pasivno pušenje, živa, endokrino aktivne tvari, pesticidi i kontaminanti prisutni u svim životnim područjima tijekom razvoja i rasta djeteta. Kako bi se poboljšalo zakonodavstvo vezano uz izloženost djece genotoksičnim i vjerojatno kancerogenim tvarima, tijekom razvoja potrebna je bolja suradnja onkologa, pedijatara, stručnjaka zdravstvene ekologije i genotoksikologa. $\mathrm{Na}$ taj način ostvarilo bi se uspješnije iskorištavanje postojećih znanstvenih podataka u cilju smanjenja incidencije karcinoma i mortaliteta.

KLJUČNE RIJEČI: genotoksikologija djece, ksenobiotik, okolišna izloženost, oštećenje genoma, transplacentalna genotoksikologija

\section{CORRESPONDING AUTHOR:}

Jelena Katić

Institute for Medical Research and Occupational Health

Ksaverska cesta 2, HR-10001 Zagreb, Croatia

E-mail: jkatic@imi.hr 